https://doi.org/10.22364/hssl.28.2.03

\title{
ADOPTION OF A PUBLIC E-PROCUREMENT SYSTEM IN UKRAINE
}

\section{Ilona Baumane-Vitolina}

Dr. oec.

\section{Oleksandr Osypenko \\ MA}

\begin{abstract}
Over the last decade Ukraine has been making attempts at creating a viable public e-procurement system that will satisfy the demands of its international partners, as well as domestic needs with the public procurement involving central governmental bodies perceived as corrupt by the public and business representatives. ProZorro.Sale became the answer to the pressing issues at hand as well as a beacon of hope for the anti-corruption efforts undertaken by the last two governments. The article explores the policy window that facilitated its launch and the latest legislative amendments introduced in order to address the drawbacks that became apparent when more and more users started interacting with the e-platform.
\end{abstract}

Key words: Ukraine, e-procurement, ProZorro.Sale, B2G relations, anti-corruption

\section{Introduction}

The omnipresence of internet technologies and the prevalence of interconnectivity between the parties engaged in various activities online allowing for the better responsiveness is changing not only the way of interaction online, but also the way business-to-government relations are developing. Developed states were among first to start implementing the innovations with regard to e-governments providing services to the population 24/7, increasing availability and transparency. Such activities include participation in public procurement and tendering that is e-procurement. E-procurement is defined as a "comprehensive process in which organizations use IT systems to establish agreements for the acquisition of products or services (contracting) or purchase products or services in exchange for payment (purchasing)" (Gunasekaran \& Ngai, 2008, p. 161). E-procurement can boast several perceived benefits that can be of strategic nature, providing companies with desired market advantage; operational benefits that help with efficiency and cost reduction of the acquisition process, like the elimination of clerical errors; and 
opportunity benefits improving the circulation of data, opening connecting the buyers with suppliers (Attaran, 2001, p. 177), just to name a few.

The developing countries are now following suit, and are greatly encouraged to implement e-procurement systems as an integral part of their e-government platforms, not only because of the previously listed benefits, but also because e-procurement in public tendering has a potential to be an anti-corruption tool, necessary to improve their anti-corruption record (Neupane et al., 2012). Business-to-government (B2G) e-trading platforms are designed to conduct and facilitate the procurements of goods and services by the government agencies from the business entities to satisfy the needs of the public sector in accordance with the current legislation. According to the 2020 study conducted by the EU Anti-Corruption Initiative, $69 \%$ of Ukrainians rate corruption as the second most important issue facing the state, it was only topped by the conflict in the East of the country $(72,7 \%)$.

Apart from the corruption perception among the population, the study also offers a review on how the business views the situation, and based on 1098 interviews conducted in 2020, public procurements with the ministries or other central government bodies are perceived as more corrupt reaching 3.73 out of 5 possible points by the EUACI system (Volosevych, 2020). The share of population knowledgeable in the issues related to corruption, or the number of those ready to refuse to engage in corrupt practices, or those ready to become a whistle-blower and uncover corruption, is considerably smaller, than desirable. Since 2011 Ukrainian government vowed to implement a novel anti-corruption system that is "mostly pre-emptive in its nature" (Mischenko, 2014, p. 36), based upon the idea of creating a number of corruption prevention mechanisms embedded into the society, and the behavioural norms and requirements put forth before the government officials for them to follow (Mischenko, 2014). Public e-procurement system quickly became a top priority there, "as it was always considered to be the most bias towards the tenderers, and the most corrupt" (Romanenko \& Shchokin, 2016, p. 27). Therefore, it required immediate action, which in return lead to the implementation of the first off Ukrainian e-procurement platform ProZorro.Sale, which, according to the analytical information presented by the platform, facilitated 1.92 million procedures related to the e-procurement processes in 2019-2020 ('Qlik Sense', 2020).

Starting from the 1990s the scientific community managed to build up quite an extensive list of literature on e-procurement, initially focusing on the successes and challenges the implementation of the system introduces (Angeles \& Nath, 2007; Chu et al., 2004; Caniato et al., 2010), policy issues (Hardy \& Williams, 2008), and implications for the public and private 
sectors (Panayiotou et al., 2004; Ash \& Burn, 2003; Williams \& Hardy, 2005). Going further, the research focused on the case studies and experiences of different regions and states had while implementing it (Mischenko, 2014; Litvinova, 2019). This article aims to shed light on the e-procurement implementation progress in Ukraine four years after the ProZorro.Sale launch with an emphasis on its anti-corruption capabilities. The article also examines legislative measures taken to ensure fairness and transparency and their implications for tender participants as the latest amendments to the Law on Public Procurements in Ukraine were adopted in order to rectify the pitfalls that became apparent after the Prozorro planform's launch.

The article is structured as follows. First, it provides an overview of e-procurement implementation and the factors that created the 'policy window' that appeared in Ukraine, enabling the state to act upon it. Careful attention is paid to the anti-corruption potential of the e-procurement platform in Ukraine. Then, a separate section is devoted to a closer look at the ProZorro.Sale system itself and its supporting bodies such as DOZORRO, that ensure its operationality, emphasised by several concrete examples of the activities associated with it. The authors examine its benefits and drawbacks, including those previously identified in other studies, in order to determine those that are still not eliminated by the new legislature and can potentially become a problem for the tenderers interacting with the platform. The study ends with a discussion of the findings.

\section{Setting Up E-procurement in the Ukrainian Public Sector. Preconditions Determining the Innovation Implementation}

Innovation in Public Procurement became one of the defining talking points for the previous and current Ukrainian governments' efforts to 'clean up the act' and reduce corruption throughout the whole sector of the economy. The setting for it was just right as "the evolution of public procurement policies in every country is embedded in a specific institutional context, it becomes inevitable to understand the factors affecting the institutionalization of PPI policies" (Lember et al., 2013, p. 288). Guided by the framework developed by Lember, Kattel, and Kalvet, this section of the article analyses the steps taken by the Ukrainian authorities in order to implement the e-procurement system in Ukraine. It was previously used to analyse public procurement of innovation, however, with mild adjustments, it can also be useful to analyse innovations in public procurement as a whole, especially when it concerns the so-called 'policy window' that appears when all factors at three levels collide. 
Table 1. Framework for mapping factors shaping public procurement policies

\begin{tabular}{|l|l|l|}
\hline Analytical level & \multicolumn{1}{|c|}{ Institutional factor } & \multicolumn{1}{c|}{ Ukrainian context } \\
\hline $\begin{array}{l}\text { International } \\
\text { pressures }\end{array}$ & $\begin{array}{l}\text { Normative pressure } \\
\text { (administrative and economic } \\
\text { policy paradigms), } \\
\text { regulatory (trade) and economic } \\
\text { (globalisation) pressure }\end{array}$ & $\begin{array}{l}\text { Pivot to the West, Association } \\
\text { Agreement between the European } \\
\text { Union and Ukraine, } \\
\text { Agreement on Government } \\
\text { Procurement (GPA) within WTO }\end{array}$ \\
\hline $\begin{array}{l}\text { Socio-economic } \\
\text { environment }\end{array}$ & $\begin{array}{l}\text { Economic background and } \\
\text { development }\end{array}$ & $\begin{array}{l}\text { Ukraine's market capabilities and } \\
\text { steadily growing e-market capacity, } \\
\text { relatively low entrance threshold, } \\
\text { growing access to internet services }\end{array}$ \\
\hline Policy context & $\begin{array}{l}\text { Polity (state structure, political } \\
\text { system and preferences) } \\
\text { Public procurement system and } \\
\text { values } \\
\text { Public procurement support } \\
\text { institutions }\end{array}$ & $\begin{array}{l}\text { Calls for democratisation, fair play, } \\
\text { and transparency }\end{array}$ \\
\hline
\end{tabular}

Source: (Authors' elaboration based on Lember et al., 2013)

International pressures played a key role in e-procurement implementation in this case, becoming a major determinant for policy changes. Since the late 2000s, Ukraine attempted to make a pivot to the West with negotiations about possible agreements launching as early as 2007 (Cabinet of Ministers of Ukraine - Association Agreement between the European Union and Ukraine, 2014). Association Agreement between the European Union and Ukraine signed in September 2014 became one of the crucial catalysts in striving for greater transparency in order for Ukraine to have a chance to be considered as a potential EU member when the next enlargement round takes place. Annex XXI to Chapter 8 of the Association Agreement deals with the public sector procurement with Article 28 calling for "use of open, restricted and negotiated procedures and competitive dialogue" and Article 30 emphasising "use of the negotiated procedure with prior publication of a contract notice" (Annex XXI to Chapter 8. Indicative Time Schedule for Institutional Reform, Legislative Approximation and Market Access, 2014) necessary to ensure due process.

Having signed the Association Agreement, Ukraine undertook a series of responsibilities, one of which concerns aligning its public procurement policies with the EU regulations, which in return paved way for the launch Harmonisation of Public Procurement System in Ukraine with EU Standards project that was called to reform the public procurement system "through the establishment of a comprehensive and transparent regulatory framework for public procurement, an efficient public procurement institutional infrastructure, the accountability and 
integrity of public authorities in regard to public procurement" ('About Harmonisation of Public Procurement System in Ukraine with EU Standards', 2013). The project then lent assistance with drafting the Law on Public Procurement establishing the system of "open bids, competitive dialogue, and negotiable procurement procedure" ('Ukraine: Law on Public Procurement', 2015). Although Ukraine was not obliged to implement e-procurement system under any of those agreements, it turned out to be the most efficient way to ensure transparency and impartiality, which consequently lead to a reduction in corruption.

April 19, 2020, saw the new version of the Law on Public Procurement come into effect that contains necessary amendments to address the pitfalls pointed out by experts and tenderers that used ProZorro.Sale platform. It sets a simplified tender offer as such that equals or exceeds UAH 50000 , but does not reach the UAH 200 000. The buyer then has an option to use the simplified tender offer or sign a direct contract with the supplier. The law also identifies a new type of procedure in public procurement to be available from October 102020 - selective tendering, that presupposes obligatory verification of the tenderer's qualifications ('Legal Developments in the New Version of the Law on Public Procurement', 2020). It should be noted, that previously such verification was only available after the auction winner was chosen, which was considered a serious drawback by several experts (Olefir, 2017; Medzhybovska \& Lew, 2019). The amendments to the Law on Public Procurement seem to make an attempt to rectify that particular issue.

Collusion remains a point of concern, where the buyer would cancel the tender citing sudden 'considerable' breach of public procurement legislation, lack of further need in the procurement item, issuing unreasonable demands to provide additional documents or coming up with different made-up reasons to not fulfil the obligations in case the 'wrong' bidder wins the auction. The recent amendments to the law provide the State Audit Service of Ukraine with the ability to hold the tenderers that practice such unfounded cancellations accountable. Penalties for gross violations grew and now amount to UAH 21000-51 000 or UAH $51000-85000$ for repeat violations. More serious corruption-related violations will see the senior officials held responsible. For instance, lodging a tender circumventing the formal prescribed by the law procedure will carry a UAH 34 000-170 000 penalty ('Legal Developments in the New Version of the Law on Public Procurement', 2020).

One more significant improvement concerns the setting the definition of the 'abnormally low price' that will be automatically determined by the system to counteract price damping. However, it does not mean that the tenderer cannot under any circumstances win the auction with 
the abnormally low price. "If a tenderer can justify the low price, then everything is in their hands. The rules for such transactions are clearly determined by the law" ('Legal Developments in the New Version of the Law on Public Procurement', 2020). It equally attempts to fix the complaint system by changing the deadlines for launching a complaint regarding violations of rights of the supplier in relation to actions or inaction of the buyer. The participant that launched a complaint will also have 3 additional days to attach any supplementary documentation necessary to consider the complaint ('Legal Developments in the New Version of the Law on Public Procurement', 2020).

Yet another crucial step in the e-procurement regulation area that has had similar effects has to do with the ratification of the Agreement on Government Procurement (GPA) which took effect in Ukraine in 2016. It imposes strict regulations and provides unified requirements to follow and aims "to open up, as much as possible, government procurement markets to international competition, make government procurement more transparent, and provide legal guarantees of non-discrimination with regard to the products, services or suppliers of any party to the Agreement" ('WTO | 2016 News items - Ukraine ratifies revised WTO procurement pact', 2016).

The socio-economic environment was also favourable for e-procurement implementation, going in tandem with the overall trend as over the last couple of years Ukrainian e-commerce market was just about the only sector of the economy that demonstrated steady growth at about 20-25\% a year, notwithstanding the general market fluctuations. Seeing that Ukraine is a developing state with the estimated e-market capacity of the equivalent of USD 400-500 million (Romanenko \& Shchokin, 2016), it could also unlock considerable previously untapped potential.

Apart from the legislative initiatives, like the Law of Ukraine 'On Prevention of Corruption' that established National Agency of Corruption Prevention, for example, that became responsible for the anti-corruption policy nationwide (The Law of Ukraine 'On Corruption Prevention', 2014), Ukraine took steps towards greater inclusion of e-government that was supposed to ensure greater transparency and access to services for everyone. One of the most important steps was to promote better public procurement by ensuring its transparency and fairness, provide the public with complete access to the procurement information, in theory, allowing its analysis and oversight, engage with the business and create competition in the sector (Public Procurement Reform, 2014). The actions were definitely required as public procurement constituted 13\% of Ukraine's annual GDP (Public Procurement Reform, 2014), amounting to almost 250 billion UAH (Romanenko \& Shchokin, 2016, p. 31). Besides, economic 
experts are convinced clandestine dealings in public procurement annually deprive the state of additional UAH 50 billion (Miniailo \& Kostenko, 2016, p. 141), therefore being marred by corruption or nepotism allegations not only interferes with the broader image of openness Ukraine was and still is striving for, but also exposes significant economic cost for the budget.

The Ministry of Economic Development and Trade of Ukraine in tandem with Transparency International Ukraine, National Bank of Ukraine, and Deposit Guarantee Fund assisted in the creation of ProZorro.Sale platform. It was conceived on the basis of the hybrid Dutch auction design with the assistance provided by the international experts such as Nobel Prize winner Roger Myerson (Main - ProZorro.Sale. About us, 2020). ProZorro.Sale adheres to the open data policy providing a public business intelligence module that contains continuously updated auction statistics intended to increase public trust in the system. Since its 24 June 2016 launch, the platform became the main podium for sales of state and communal property that equally strives to fight corruption "by the means of equal access to data, public control and through increasing the number of the potential buyers" (Main - ProZorro.Sale. About us, 2020). According to the information provided by the ProZorro.Sale website, they started by selling the property of the insolvent banks and within a year managed to facilitate 1 billion UAH worth of transactions, whereas since its launch until 2020 total volume of transactions through the platform reached the equivalent of 890 million USD with over 15 thousands registered participants (Main - ProZorro.Sale. About us, 2020). Gradually ProZorro. Sale took over the whole public procurement sector operating nationwide and overseeing transactions exceeding $200000 \mathrm{UAH}$, with the Ministry of Economic Development and Trade representative Maksim Nevzorov highlighting the fact that the system allowed savings amounting to around $11.5 \%$ on average with items that were auctioned through it in comparison with the previously used system ('ProZorro Status Quo and Prospects', 2017).

Now, in line with the greater transparency policy, the Centre for Journalism at Kyiv School of Economics offers practicing journalists a chance to improve their knowledge of public procurement system with the newest free of charge course "Economics, Markets, and Data Analysis" providing the media representatives with the opportunity to properly analyse and visualise the information supplied by the ProZorro.Sale website and DOZORRO platform. The course is financed by USAID and UKAID Tapas Project supporting transparency and accountability in public procurement and services in order to combat corruption and boost trust in the Ukrainian government based on the proven transparency and accountability throughout the government offices ("Economics, Markets 
and Data Analysis program for journalists", 2020). Generally, the aspiration is that after taking the course journalists will be able to better verify the open data on public procurements made available by the platforms, as well as the government and convince the public and businesses that there are no behind-the closed-doors deals that lead to corruption in the past.

Kyiv School of Economics was also engaged in research regarding the harmful effects of the localisation regulation in machine-building procurement in Ukraine. According to their calculations making the localisation bill into law that restricts mechanical engineering imports in favour of the domestic manufactures in public procurement would cause $0.5 \%$ drop in Ukraine's GDP and, what is more important, would roll back some of the positive effects the reforms in public procurement were having on the economy (TI Ukraine, 2020).

The aforementioned Tapas project also plays an important role aiming to fight corruption supporting the e-governance reform in Ukraine and implementing best practices observed globally in e-procurement, open data, and e-government services. Tapas is collaborating with the Ukrainian government and civil society to improve the existing ecosystem and help reduce corruption levels to make Ukraine more attractive to businesses (“About Tapas Project", 2020).

The overall effects from the efforts to improve G2B relations become apparent analysing some of the data provided by the World Bank Doing Business ranking where in 2020 Ukraine was placed on 64th spot judging by the ease of doing business score and $61^{\text {st }}$ judging by the ease to start a business, which is a definite improvement in comparison with 2019 when the country ranked $71^{\text {st }}$ and $2018^{\text {th }}$ when Ukraine occupied $76^{\text {th }}$ place (The World Bank, 2020). Such improvements in G2B relations are also promoted by the Better Regulation Delivery Office (BRDO) that strives to improve the Ukrainian business environment, attract investment, promote the development of entrepreneurship, and establishing a dialogue between the government and businesses. Their activities regarding market supervision include close engagement on resolving the issues with the public procurement system in Ukraine, including facilitation of the procurement review process that should improve the overall ecosystem in the country ("BRDO and CBU discussed public procurement issues with construction market stakeholders - Better Regulation Delivery Office”, 2019).

\section{ProZorro.Sale: Benefits and Drawbacks}

Since 2017, ProZorro.Sale introduced an option to participate not only in the auction designed specifically for the platform since its inception, but 
also in the so-called 'Dutch auction' that is operating based on the following principles "designed specifically to increase the speed of sale, and tackle the comparative advantage of the insiders" (Shapoval et al., 2019, p. 13):

1) all the bidders are engaging with the seller on equal terms;

2) descending clock auction determines the 'Dutch winner' which essentially is the first bidder that claims the lot at the acceptable price after the auction first stage begins;

3 ) the second stage of the auction is the secretly submitted sealed bids in which the 'Dutch winner' does not participate. To win at this stage the participant has to be the highest bidder, the participants know the total number of bidders (Shapoval et al., 2019); and

4) the 'best bid' stage allows the 'Dutch winner' to compete for the lot with the sealed bid winner. Best bid wins the tender ${ }^{1}$ ('Hybrid Dutch auction (Insider) - Atreus SaaS Auction Platform', 2020).

Bi.ProZorro.sale interactive data analytics module is another integral part of the system that allows public oversight through access to open data available on every procurement made through the platform. The oversight is vested into DOZORRO monitoring portal that encourages tenderers to provide feedback and grade their experience engaging with ProZorro.Sale, which in return can potentially lead to changes in the system in case there are frequent grievances over particular issues from the businesses.

The Ukrainian e-procurement platform also admittedly boasts some significant benefits. First and foremost, its replicability has already sparked interest from other states, that are interested in implementing similar technology. Sweden, for example, is now reportedly looking into ProZorro.Sale in order to implement the Open Procurement portal, which will replicate the Ukrainian model, at the national level. By the country's estimation, it is expected to allow saving up to 7 billion SEK a year, an equivalent of the $1 \%$ of the total cost of procurement. The general belief is that "the open contracting will enable the government to provide services of a higher quality for the same price, while citizens will be able to understand how their taxes are spent and to prevent corruption and mistakes in tenders in time" ('Sweden to Adopt Ukraine's Procurement Practices | Transparency International Ukraine', 2020).

The other benefit is the cost of launch, which is relatively low. The platform even won 2016 World Procurement Award in the Public Sector as well as 2019 Global Public Service Teams of the Year award in the 'Doing More for Less' category, indicating that the cost of the launch

Detailed description of the Hybrid Dutch Auction is available at Atreus Auction Software Hybrid Dutch auction (Insider) -Atreus SaaS Auction Platform. Atreus SaaS Auction Platform. (2020). Retrieved 15 February 2020, from https://atreus.auction/auctions/hybrid-dutchauction/. 
was as little as USD 100,000, however, since then it helped generate more than USD 500 million in revenue ('Apolitical Announces 2019 Global Public Service Teams of the Year', 2019). Besides, it can be launched within 6 months, which is an attractive feature, especially if a state needs to act fast to demonstrate results and willingness to push for the transparency updates in the public procurement sector.

Benefits for the business side include greater access to the public procurement market and a chance to compete for lucrative governmental tenders with relatively low threshold levels starting from UAH 200000 for goods and services and UAH 1.5 million for works, which theoretically opens up public procurements to small and medium enterprises (SMEs). Contracts in public procurement in Ukraine are also drawn for a year which guarantees profits within that period. Some of the Ukrainian SMEs then work exclusively within the contract, engaging only with their public procurement counterparts (Miniailo \& Kostenko, 2016).

The amendments to the Law on Procurement now also call for all the buyers from governmental agencies to report every procurement that does not exceed UAH 50000 by registering it through ProZorro system which is supposed to increase transparency and accountability. To uphold this decision, the Ministry of Economic Development and Trade of Ukraine recently published a draft decree 'On Adoption of the Regulatory Procedure to Oversee the Launch and Use the Electronic Catalogue' that concerns a new feature - the ProZorro Market - a national e-store designed to handle the pre-threshold procurements up to UAH 50000 , destined for the needs of the governmental institutions, from the most mundane, like disposable cutlery, to more sophisticated ones ('On Adoption of the Regulatory Procedure to Oversee the Launch and Use the Electronic Catalogue', 2020). Overseeing the e-store is Centralized Purchasing Organization (CPO) 'Professional Procurements", created to resolve the following issues: "professionalizing of public procurement sector, increasing cost savings through volume aggregation, procurement standardization, and reducing the level of corruption" ("Cabinet of Ministers of Ukraine Centralized procurement agency set up in Ukraine', 2019).

ProZorro.Sale allows to leave feedback or effectively launch a complaint using the DOZORRO website as an intermediary, which is an important step in accordance with the roadmap drawn up after GPA ratification. Another plus is a possibility to participate in the free of charge training and workshops arranged by the ProZorro team, which according to the ProZorro reports amounted to 100 events with about 2500 business circles representatives actively participating in the 2016-2017 period ('ProZorro Status Quo and Prospects', 2017). For those wishing to obtain a certificate, there is also an official 2 weeks public procurement 
course with experts from Transparency International Ukraine, ProZorro coordinators, and GPA in Ukraine representatives providing classes on practical aspects of how to launch a complaint or more effectively engage with the platform as well as some general advice on public procurement in Ukraine ('Public Procurement for Business', 2017).

However, despite the amendments to the Law on Public Procurements, which did rectify some of the faults previously found with the platform, the system is still not without its shortcomings. First of all, it concerns the practice of fractionalisation of the tender amount in order to avoid the proper procedure that follows tenders exceeding UAH 200000 threshold for goods and services and UAH 1500000 for works (Olefir, 2017, p. 4). For instance, in December 2017, Panutin Railway Car-Repair Plant held 64 identical tenders to purchase replacement parts, the summary total for a single tender would have been UAH 235 million (Stepankovska, 2018). Another example, in 2018, the Poltava City Council Education Department avoided participating in the ProZorro tendering system when procuring Christmas gifts for schoolchildren by purchasing the aforementioned gifts in smaller batches, lower in value than UAH 200 000, even though the total value of the tender, were it purchased in a single batch, would have amounted to UAH 1781000 , which is well above the threshold. In addition, the local journalists pointed out that the wholesale price of each individual gift purchased by the Education Department was higher than the market retail price (Samoiduk, 2019). Up until now, the ProZorro platform provided no mechanism that targets fractionalisation so there are likely to be other attempts at playing the system this way. Besides, the last example touches upon one more issue that became apparent after the platform's launch: participation in an online auction "does not guarantee the buyer accepting the cheapest option available on the market due to a variety of factors, such as suppliers refusing to participate in tenders because buyers often request to lower the price; overextension of the expected value of the procurement item" (Olefir, 2017, p. 4), etc.

Probably the most widespread criticism concerns the fact that control over the qualification-based selection of the prospective suppliers, which provides the buyer with ample possibilities to tailor the qualification criteria in a way that only fit the 'necessary' enterprises, like when "the buyer adjusts the criteria in any way that fits his agenda so that a bogus company can win the tender; some criteria are discriminatory in nature" (Olefir, 2017, p. 7). For example, the Road Service in Vinnytsia region manipulated the tender for road repair works that amounted to UAH 306 million in such a way, that the only possible winner for it was the Rostdorstroy firm that was closely connected to Odesa mayor Gennadiy Trukhanov. The buyer stipulated that to qualify the tenderers should have their own, rented or 
leased bitumen concrete plant with 100 tons per hour capacity situated close to the designated work area, not exceeding $150 \mathrm{~km}$. Due to this requirement, the Turkish company Onur Construction International was disqualified, even though its offer was more profitable (Sheitenko, 2018).

Another loophole in the system is related to tender concealment through the erroneous definition of the procurement item in order to provide an opportunity to participate exclusively to the predetermined tenderers and eliminate everyone else who might become competition (Medzhybovska \& Lew, 2019), providing an opportunity for collusion. A characteristic example here will be machinations attempted by Lutsk public electric transport facility that in 2017 announced a tender for technical reequipment of the city trolleybuses with the aim to arrange it as a pre-threshold procurement procedure even though the tender amounted to UAH 3356000 . Additionally, the buyer inaccurately defined the procurement item labelling equipment removal as 'works' instead of 'services' which in fact allowed Lutsk public electric transport facility to acquire a pre-threshold procedure status for the tender. Transparency International Ukraine expert Myroslava Prymak explained that "if the buyer participates in a public auction, the procurement then is covered by the Law on Public Procurements and all the discrepancies are punishable under administrative procedure" (Kutz, 2017). However, the pre-threshold auctions are not covered by the said law, instead, they are to follow ProZorro Decree № 35 which is advisory in its nature, and the tenderers are not liable for any discrepancies or violations. The recent amendments to the Law on Public Procurements decreased the penalties for procedural violations sevenfold, therefore erroneous definition of the procurement item now only carries UAH 1700 fine, which is the equivalent of USD 63 instead of UAH 11700 which equal to USD 437. Whether such actions will grow in number as a result, tempting more tenderers to engage in collusion without the risk to be subject to severe penalties remains to be seen. That said, the State Audit Service of Ukraine now has the ability to impose penalties on the offenders independently, without referring the case to court, leading to a speedier response from the overseeing body, which may, in theory, become a deterrent.

\section{Discussion}

The policy window that opened for Ukraine to create its own e-procurement platform was hailed as one of the greatest achievements by the Ukrainian experts. It is now reaching the level of integration into the system necessary to make a difference throughout the sector with almost any public procurement having to be registered into the system. 
Despite the evident achievements, benefits, and improvements that the platform ensures, previously conducted studies came up with various valid reasons to critique the ProZorro.Sale and its corruption prevention mechanisms. The anti-corruption capabilities for such platforms are indeed questioned quite frequently, with some scholars pointing out they can hardly agree such platforms have the necessary potential to single-handedly limit the volume of the corruption-related illicit activities in any given country (Shentov et al., 2011). The evidence in Ukraine also demonstrates that anti-corruption efforts are not always perceived in a positive light with studies indicating that after the launch of ProZorro in 2016 the corruption perception index did not improve in a significant way, moreover, in 2020 the degree of corruption perception among the population grew in comparison with 2017.

Another staggering thing is, the corruption perception of the National Agency of Corruption Prevention and the National Anti-Corruption Bureau grew the most from 3.61 to 3.95 and from 3.56 to 3.92 respectively. It is even more noticeable with the business sector, where those NACP now has 3.24 points instead of 2.91 in 2017 and 3.29 instead of 2.69 points (Volosevych, 2020). The proposed changes to the Law on Public Procurement improved the system and eliminated some of the most prominent risks that existed in the e-procurement system, however, the amendments to the law are recent and they did not yet influence the 2020 corruption perception index, the effect it will have on the business-to-government relations, and a possible shift in corruption perception that will take place after the amended law comes into force need to be studied more thoroughly. At the moment it is possible to say that they have the potential to eliminate much criticism directed at ProZorro itself and the anti-corruption efforts in Ukraine in general. The addition of a coherent legal framework would be the key component to ensure the success of this venture. This requires political will from the state authorities and a considerable push from the public. In a situation where some individuals in a position of authority are acting as a major corruption source, ensuring such political will and controlling the implementation of the necessary laws should ideally fall to the population, which makes raising awareness about corrupt practices becomes vital. In this regard, work conducted by DOZORRO, TI Ukraine, and other overseeing bodies becomes the bridge between the needs of the businesses and the legislative branch.

\section{REFERENCES}

About Harmonisation of Public Procurement System in Ukraine with EU Standards. Eupublicprocurement.org.ua. (2013). Retrieved 16 April 2020, from https:// eupublicprocurement.org.ua/about-project?lang=en. 
About Tapas Project. TAPAS. (2020). Retrieved 19 April 2020, from http://tapas.org.ua/ pro-proekt/.

Angeles, R., \& Nath, R. (2007). Business-to-business e-procurement: success factors and challenges to implementation. Supply Chain Management: An International Journal, 12(2), 104-115. https://doi.org/10.1108/13598540710737299.

Apolitical Announces 2019 Global Public Service Teams of the Year. Apolitical. (2019). Retrieved 15 March 2020, from https:/apolitical.co/en/solution_article/apoliticalannounces-2019-global-public-service-teams-of-the-year?fbclid=IwAR2hDjaNJxg7c1v52P4-meCI0jHuHGp5kVI25Th2N5zjeGZS8RhBrVQfOs.

Ash, C., \& Burn, J. (2003). Assessing the benefits from e-business transformation through effective enterprise management. European Journal of Information Systems, 12(4), 297-308. https://doi.org/10.1057/palgrave.ejis.3000476.

Attaran, M. (2001). The coming age of online procurement. Industrial Management $\mathcal{E}$ Data Systems, 101(4), 177-181. https://doi.org/10.1108/02635570110390080.

$B R D O$ and $C B U$ discussed public procurement issues with construction market stakeholders Better Regulation Delivery Office. En.brdo.com.ua. (2019). Retrieved 19 July 2020, from https://en.brdo.com.ua/main/brdo-cbu-discussed-public-procurement-issuesconstruction-market-stakeholders/.

Cabinet of Ministers of Ukraine - Centralized procurement agency set up in Ukraine. Kmu. gov.ua. (2019). Retrieved 28 April 2020, from https://www.kmu.gov.ua/en/news/vukrayini-stvorena-persha-centralizovana-zakupivelna-organizaciya.

Chu, P., Hsiao, N., Lee, F., \& Chen, C. (2004). Exploring success factors for Taiwan's government electronic tendering system: behavioral perspectives from end users. Government Information Quarterly, 21(2), 219-234. https://doi.org/10.1016/j. giq.2004.01.005.

Economics, Markets and Data Analysis program for journalists. Kyiv School of Economics. (2020). Retrieved 19 April 2020, from https://kse.ua/kse-program/ceej-economicsmarkets-and-data-analysis/.

Gunasekaran, A., \& Ngai, E. (2008). Adoption of e-procurement in Hong Kong: An empirical research. International Journal of Production Economics, 113(1), 159-175. https://doi.org/10.1016/j.ijpe.2007.04.012.

Hardy, C., \& Williams, S. (2008). E-government policy and practice: A theoretical and empirical exploration of public e-procurement. Government Information Quarterly, 25(2), 155-180. https://doi.org/10.1016/j.giq.2007.02.003.

Hybrid Dutch auction (Insider) - Atreus SaaS Auction Platform. Atreus SaaS Auction Platform. (2020). Retrieved 15 February 2020, from https:/atreus.auction/auctions/ hybrid-dutch-auction/.

Kmu.gov.ua. 2014. Annex XXI To Chapter 8. Indicative Time Schedule For Institutional Reform, Legislative Approximation And Market Access. [online] Available at: < https:// www.kmu.gov.ua/storage/app/media/Annexes\%20of\%20title\%20IV/ANNEX\%20 XXI\%20TO\%20CHAPTER\%208.pdf> [Accessed 14 April 2020].

Kmu.gov.ua. 2014. Cabinet Of Ministers of Ukraine - Association Agreement Between The European Union And Ukraine. [online] Available at: <https://www.kmu.gov.ua/ en/yevropejska-integraciya/ugoda-pro-asociacyu > [Accessed 14 April 2020].

Kutz, V. (2017). Trolleybus Modernization in Lutsk. The Pseudo Tender Allowed to Give 3 Million to the Co-Conspirator Firm. Chetverta Vlada. Retrieved 18 March 2020, from https://4vlada.com/investigations/51397. 
Legal Developments in the New Version of the Law on Public Procurement. E-tender.ua. (2020). Retrieved 18 April 2020, from https://e-tender.ua/news/novovvedennya-unovij-redakciyi-zakonu-pro-publichni-zakupiv-441.

Lember, V., Kattel, R., \& Kalvet, T. (2013). How Governments Support Innovation Through Public Procurement: Comparing Evidence from 11 Countries. Public Procurement, Innovation And Policy, 287-309. https://doi.org/10.1007/978-3-64240258-6_14.

Litvinova, T. (2019). Development of E-government in Russia: Problems and Prospects. Journal of Law And Administration, (3), 60-68. https://doi.org/10.24833/2073-84202018-3-48-60-68.

Me.gov.ua. 2014. Public Procurement Reform. [online] Available at: <https://www. me.gov.ua/Documents/Detail lang $=$ uk-UA\&id =38c083f3-2571-466a-9583-3b43c2 804ad9\&title $=$ ReformaDerzhavnikhZakupivel $>$ [Accessed 14 April 2020].

Medzhybovska, N., \& Lew, A. (2019). Micro businesses participation in public procurement: Evidence from Ukraine. Economics \& Sociology, 12(3), 98-113. https:// doi.org/10.14254/2071-789x.2019/12-3/7.

Miniailo, O., \& Kostenko, A. (2016). Current State and Development Prospects of the Electronic Public Procurement in Ukraine. University Economic Journal, 29(1), 135-144.

Mischenko, R. (2014). Preventing And Fighting Corruption In Public Procurement: Analysis Of The Ukrainian And Foreign Experience. ACTUAL ISSUES OF MODERN SCIENCE AND SOCIETY, 1, 34-40. Retrieved 14 April 2020, from https:// cyberleninka.ru/article/n/predotvraschenie-i-protivodeystvie-korruptsii-v-sferegosudarstvennyh-zakupok-analiz-opyta-ukrainy-i-zarubezhnyh-stran/viewer.

Neupane, A., Soar, J., Vaidya, K., \& Yong, J. (2012). Role Of Public E-Procurement Technology To Reduce Corruption In Government Procurement. In International Public Procurement Conference. Seattle, Washington. Retrieved 14 April 2020, from https://core.ac.uk/download/pdf/11049357.pdf.

Olefir, A. (2017). Problems of public procurement in comparison with European experience. Theory And Practice Of Jurisprudence, 11(1).

Panayiotou, N., Gayialis, S., \& Tatsiopoulos, I. (2004). An e-procurement system for governmental purchasing. International Journal of Production Economics, 90(1), 79-102. https://doi.org/10.1016/s0925-5273(03)00103-8.

On Adoption of the Regulatory Procedure to Oversee the Launch and Use the Electronic Catalogue. Me.gov.ua. (2020). Retrieved 12 May 2020, from https://www.me.gov. ua/Documents/Detail?lang = uk-UA\&id =fd9753a2-6488-43bb-8e52-1b64cbaf7021 \&title $=$ ProektPostanoviKabinetuMinistrivUkrainiproZatverdzhenniaPoriadkuFor muvanniaTaVikoristanniaElektronnogoKatalogu.

Prozorro.sale. 2020. Main - Prozorro.Sale. About Us. [online] Available at: <https:// prozorro.sale/en> [Accessed 14 April 2020].

ProZorro Status Quo and Prospects. Issuu. (2017). Retrieved 16 March 2020, from https:// issuu.com/mineconomdev/docs/prozorro

Public Procurement for Business. Courses.prometheus.org.ua. (2017). Retrieved 16 April 2020, from https://courses.prometheus.org.ua/courses/course-v1:ProZorro+ PP202+2017_T1/about.

Romanenko, E., \& Shchokin, R. (2016). Reformation Of The System Of Public Procurement In Ukraine. Public Management, 25-34. Retrieved 14 April 2020, from 
https://cyberleninka.ru/article/n/reformirovanie-sistemy-gosudarstvennyh-zakupok-v-ukraine.

Samoiduk, M. (2019). Authorities in Poltava Announced a Tender to Purchase Christmas Gifts for the Children. Its Expected Value Amounts to 2,2 Million Hryvnias. Zmist. Retrieved 18 March 2020, from https://zmist.pl.ua/news/poltavska-vlada-ogolosilatender-na-pridbannya-novorichnih-naboriv-dlya-ditei-ochikuvana-vartist-22miliona-griven.

Shapoval, N., Brik, T., Mylovanov, T., Vohra, R., Sobolev, O., \& Mykhaylov, I. (2019). Selling non-performing loans: new evidence from Ukraine. Kyiv: Kyiv School of Economics. Retrieved from https://kse.ua/wp-content/uploads/2019/05/NPL-KSE-04.22.2019.pdf.

Sheitenko, Y. (2018). Appealing Against the Road Repairs Public Procurement Where the Winning Company Close to Truchanov Was Caught Violating the Procedure. украв / ukr.aw. Retrieved 23 April 2020, from https:/ukr.aw/case/oskarzhujemo-zakupivlyudorozhnykiv-de-z-porushennyam-peremohla-kompaniya-z-orbity-truhanova/.

Shentov, O., Todorov, B., \& Yordanova, M. (2011). Anti-corruption in public procurement: balancing the policies. Center for the Study of Democracy.

Stepankovska, Y. (2018). How to Fool ProZorro. 7 Tricks. Glavcom. Retrieved 18 March 2020, from https:/glavcom.ua/economics/finances/yak-obduriti-prozorro-simsposobiv-524647.html.

Sweden to Adopt Ukraine's Procurement Practices | Transparency International Ukraine. Transparency International Ukraine. (2020). Retrieved 15 April 2020, from https:// ti-ukraine.org/en/news/sweden-to-adopt-ukraine-s-procurement-practices/.

The World Bank. (2020). Ease of Doing Business rankings. World Bank. Retrieved 19 June 2020, from https://www.doingbusiness.org/en/rankings.

TI Ukraine. (2020). Localization Would Harm Economy - Research | Transparency International Ukraine. Трансперенсі Інтернешнл Україна. Retrieved 19 July 2020, from https://ti-ukraine.org/en/news/localization-would-harm-economy-research/.

Qlik Sense. Bi.prozorro.org. (2020). Retrieved 15 April 2020, from https://bi.prozorro. org/sense/app/fba3f2f2-cf55-40a0-a79f-b74f5ce947c2/sheet/HbXjQep/state/ analysis\#view/q6zpiXHy.

Ukraine: Law on Public Procurement. Cms-lawnow.com. (2015). Retrieved 16 March 2020, from https://www.cms-lawnow.com/ealerts/2015/12/ukraine-law-on-publicprocurement.

Volosevych, I. (2020). Corruption in Ukraine 2020. Nazk.gov.ua. Retrieved 23 April 2020, from https://nazk.gov.ua/wp-content/uploads/2020/05/Corruption_Survey_2020_ Presentation_Info-Sapiens.pdf.

Williams, S., \& Hardy, C. (2005). Public e-Procurement as socio-technical change. Strategic Change, 14(5), 273-281. https://doi.org/10.1002/jsc.728.

WTO | 2016 News items - Ukraine ratifies revised WTO procurement pact. Wto.org. (2016). Retrieved 15 March 2020, from https://www.wto.org/english/news_e/news16_e/ gpro_18apr16_e.htm.

Zakon.rada.gov.ua. 2014. The Law of Ukraine 'On Corruption Prevention'. [online] Available at: <https://zakon.rada.gov.ua/laws/show/1700-18> [Accessed 14 April 2020]. 